\title{
Commanding heights, levers of power: A reconnaissance of post-war education reform
}

\author{
Puestos de mando, palancas del poder: \\ Un reconocimiento de la reforma educativa \\ de la postguerra
}

\section{Sommets du commandement, niveaux de pouvoir : Une connaissance de la réforme de l'éducation d'après-guerre}

\author{
Josh Cole \\ Queen's University, Canada \\ lan McKay \\ Queen's University, Canada
}

\begin{abstract}
Throughout the second half of the twentieth century - from the years of the Fordist welfare state to those of the post-Fordist neo-liberal order - educational systems in the West have fostered ambitious schemes promoting wide-ranging 'progressive change.' Equally ambitious Marxist critiques have targeted education's regulatory role within the capitalist system. In the early twenty-first century, as privatization and the radical subordination of educational aims and objectives to the demands of capital ('neo-liberalism') become unavoidable topics of educational debate, resistance to such neoliberal projects demands a rigorous reconnaissance of the achievements and limitations of radical educational thought. After canvassing major critics of mainstream schooling inside North America and beyond, we suggest that a radical retrieval of the insights of C. B. Macpherson and especially Antonio Gramsci can move us far beyond both reductionist Marxism and unreflective liberalism. We take a third position - embodying an individualist and collective pedagogy - in which the much-maligned 'liberal arts' stand against 'possessive individualist' education reform.
\end{abstract}


Key words: Marxism, liberalism, democracy, educational history, education reform, educational studies, liberal arts, hegemony, post-war history, contemporary history.

\section{RESUMEN}

A lo largo de la segunda mitad del siglo XX - desde los años del bienestar del fordista hasta aquellos del orden neoliberal postfordista - los sistema educativos en occidente han promovido ambiciosos sistemas que fomentaban un amplio 'cambio progresivo.' Las críticas marxistas igualmente ambiciosas tomaron como objetivo el rol regulatorio de la educación dentro del sistema capitalista. En el inicio del siglo XXI, al tiempo que la privatización y la subordinación radical de los objetivos y propósitos de la educación a las demandas del capital ('neoliberalismo') se convertían en inevitables temas del debate educativo, la resistencia a estos proyectos neoliberales demanda un reconocimiento riguroso de los logros y limitaciones del pensamiento educativo radical. Una vez escrutadas las principales críticas de la escolarización dentro de Norteamérica y más allá, sugerimos que una recuperación radical de las ideas de C B. Macpherson y especialmente de Antonio Gramsci, puede llevarnos más lejos de lo que lo han hecho el marxismo reduccionista y el liberalismo no reflexivo. De este modo, abrimos una tercera posición - envolviendo una pedagogía individualista y colectiva - en la que las ampliamente difamadas "artes liberales" se ubican en contra de la reforma educativa "individualista posesiva."

Descriptores: Marxismo, liberalismo, democracia, historia de la educación, reforma educativa, estudios educativos, artes liberales, hegemonía, historia de la postguerra, historia contemporánea.

\section{RÉSUMÉ}

Tout au long de la deuxième moitié du vingtième siècle - depuis les années de l'État providence Fordiste jusqu'à celles de l'ordre néo-libéral post-Fordiste - les systèmes d'éducation dans l'Ouest ont préconisé des plans (projets, procédés) ambitieux, faisant la promotion de «changements progressistes» à grande échelle. De même les critiques des Marxistes ont visé le rôle réglementaire de l'éducation au sein du système capitaliste. Dans les premières années du 21 e siècle, alors que la privatisation et la subordination radicale des buts et objectifs de l'éducation aux demandes du capital (le néo-libéralisme) deviennent des sujets inévitables du débat sur l'éducation, la résistance à de tels projets néolibéraux exige une reconnaissance rigoureuse des accomplissements et des limitations de la pensée radicale sur l'éducation. Après un sondage des critiques majeurs de l'enseignement général en Amérique du Nord et au-delà, nous suggérons qu'une récupération radicale de C. B. MacPherson, et spécialement de Antonio Gramsci, peut nous amener à dépasser de beaucoup le Marxisme réductionniste et le libéralisme irréfléchi. Nous prenons alors une troisième position - incarnant une pédagogie et individualiste et collective - dans laquelle les 'arts libéraux' très critiqués s'opposent à la réforme éducative 'individualiste possessive.'

Mots clés: Marxisme, libéralisme, démocratie, histoire de l'éducation, réforme de l'éducation, les études éducatives, les sciences humaines, l'hégémonie, I'histoire d'après-guerre, l'histoire contemporaine.

\section{Introduction}

"If you know the enemy and know yourself, you need not fear the result of a hundred battles. If you know yourself but not the enemy, for every victory gained you will also suffer a defeat. If you know neither the enemy nor yourself, you will succumb in every battle." (Sun Tzu, The Art of War.) 
$\mathrm{H}_{\mathrm{t}}$ ERE, WE OFFER A "RECONNAISSANCE" OF EDUCATIONAL EVENTS AND IDEAS, from the long-1960s - or, 1945-1975 - to the present. This approach to historical research can be thought of as "a preliminary examination or survey, as of the territory and resources of a country." Further, it is meant to serve as an "act of obtaining information of military value, especially regarding the position, strength, and movement of enemy forces" (McKay, 2008, p. 1). It strives to combine the practical and the theoretical, for it matters greatly how one conceptualizes the social order, because informed activism requires accurate information (much as an informed military struggle requires an accurate map). In this sense, its philosophical roots are in realism, not idealism. In other words, we wish to provide information for scholars, but also tools for activists. Our provisional conclusions are as follows: the long-1960s generated a utopian moment in education, in which leftists and liberals worked side-by-side to elevate the state apparatus in the name of individual liberation and social justice. Faith in this project was lost as this radical democratic hegemony splintered under the pressure of government repression, war, and the seeming futility of achieving equality and justice through the machinery of government. After this point, the left turned away from public education, developing a sophisticated critique of pedagogy as class reproduction and social control. While this was happening on the left, a neglected 'new right' emerged, and began to further its own hegemonic project through education reform. By the turn of the twenty-first century, this project had become hegemonic, endorsed by governments and financial elites alike. The leftist critics who turned their backs on the utopian potential of public schooling did nothing to stop it - in fact, they added fuel to the fire through their attacks in public education. That said, all is not lost. Traces of the 1960s radical democratic project remain, as wholly new iterations of public schooling as a vehicle for individual growth and democratic development emerge. In addition to this, existing theoretical resources can be tapped to further this radical democratic project.. Thus, we end on a note of hope for a new hegemony maximizing the liberatory potential of contemporary public education as part of a wider radical democratic project. ${ }^{1}$

\section{The Sixties and radical optimism}

In order to grasp the shape of post-war education reform in the Anglo-American world, we must begin in what historians refer to as the long-1960s - the period from 1945 to 1975 - before moving to the 1960 s proper, and then beyond. The British historian Eric Hobsbawm (2004) has argued that what distinguished the quartercentury after the end of the Second World War in the West was the fact that liberaldemocratic states - just like their Marxist counterparts - were desperate to stave off economic depression and a return to the extreme politics of the 1930s (pp. 225286). ${ }^{2}$ Thus, they embarked upon social and economic planning to an unprecedented degree. To speak of capitalism in the long-1960s is to speak of a capitalism modified radically. As the British Prime Minister Harold Wilson described it, this was modernity in action, the democratic application of "scientific research to industrial life" (quoted in O'Hara, 2007, p. 1). Thus, the long-1960s saw the mainstreaming of Keynesian economics, the development of the 'welfare state' in its various forms, and 
the military-industrial complex - an income-redistribution program of unprecedented scale. For the quarter-century following the war, it worked brilliantly. Economic growth reached unprecedented levels, and prosperity was spread evenly among the booming populations of the West.

Knowledge and education were crucial to this undertaking. There was a remarkable consensus within and among post-war nation-states that education was an economic, social, and political panacea. Thus, schools, universities, and other educational sites came to enjoy unprecedented support, growth, and prestige after 1945, reaching a peak in the 1960s. This pedagogical thrust was enhanced by the Cold War, which saw power and knowledge intertwined as never before. After the first Sputnik satellite was launched by the USSR in 1957, the liberal-democracies of the West panicked, fearing that the Soviet Union was in possession of an ill-understood, yet demonstrably superior education system. In retaliation, the United States began funding education at record levels, and experimenting with pedagogy on a mass-scale (Kliebard, 2004, pp. 266-270). ${ }^{3}$

They were not alone. By the mid-1960s, Britain had raised a rump of previously obscure progressive educators to senior positions in the Ministry of Education, and began supplementing their 'Oxbridge' model of higher education with six new 'Redbrick Universities' located in industrial areas (Lowe, 2007; Peers, 1943). Further, by the end of the decade, Canada - moving swiftly from colony to nation - was spending more than Britain, the United States, and the Soviet Union on education and educational research (Wilson, 1997).

For a time, the results were electric. As the American historian Diane Ravitch (1983) points out, both education and the idea of education as a public good absorbed all the "energy youth, and dynamism" of the decade. It united "federal agencies, university scholars, major philanthropic foundations, big-city school systems, and almost everyone else in the field" (pp. 232-233). Leftists that had worked outside of the system for decades were drawn back in by the promise of a truly 'progressive' system, backed by the power of the state. Thus, approaches that would have been considered radical before the 1960s were mainstreamed, including grassroots experiments in ungrading, team-teaching, interdisciplinarity, educational television, and Skinnerian teaching machines. Most important and influential of all was the US Head Start program of pre-schooling for low-income children (Ravitch, 1983, p. 159).

Underlying all of these developments was an assumption - shared by leftist activists, technocratic liberals, politicians, and the business community - that society could only progress if the individual was made free and democratic through an enhanced liberal education in tune with profound changes in the lives of individuals and the society they share. That is, what was achieved for a short period of time was a form of radical democracy, in which liberals and socialists alike worked toward a new way of thinking about society, one that dialectically went beyond existing ideological positions. Crucially, it was not a merger of disparate elements, but a transformation of them both.

We can see this radical democracy coursing through the long-1960s, and the 1960s proper. For instance, the American sociologist C. Wright Mills (1967) urged 
his readers to address "the individual as a biographical entity" intertwined with "the social setting that is directly open to his personal experience" (pp. 395-396). The famous Port Huron Statement of 1962 argued that the individual was born free, before being artificially "manipulated into incompetence" by industrial society - a process that they wished to reverse by liberating society, and thus the individual (reprinted in Miller, 1987, p. 332). The widespread Anglo-American interest in existentialism during the 1960s also points in this direction - particularly its rapprochement with Marxism in Sartre's Search for a Method and Critique of Dialectical Reason, as well Simone de Beauvoir's seminal The Second Sex, in which she argued that women were born as individuals, before being forced into repressive gender roles by society. The philosopher Herbert Marcuse's bestselling works at once served as searing indictments of oppressive social structures and pleas for utopian personal liberation. The famous 1960s feminist phrase summed it up best: 'the personal is political.'

For a brief period of time during this 'decade of revolutions,' the realization of individual freedom, concern for social justice, and educational arraignments embodying these twin values stood together as hegemonic 'common sense' - a seemingly natural arrangement, enjoying (freely-given) consent among a majority of AngloAmerican populations. This moment would not last, however.

\section{Neo-liberal counter-hegemony}

While this radical democracy reached a peak with War on Poverty and Head Start, a 'New Right' was also coalescing. The organic intellectuals involved would prove much more focused and resourceful over time than their leftist/liberal counterparts, and thus much more successful. This success can be measured by the fact that, as we write in 2014, it is their project - education as 'possessive individualism,' or the reduction of human capacities to the logic of the capitalist marketplace - and not the radical democratic project of the 1960s, that is hegemonic in the Anglo-American world. We focus on charter schooling as a crucial test-case here, but the reader should bear in mind that post-1960s New Right neo-liberal social policy has a much wider ambit: it is, at its root, a transnational project, emanating from many independent hands, that seeks to remake society through "privatization, deregulation, and unfettered free markets over public institutions and governments" (Clune, 2013).

As Alice Echols (2002) argues, no one who was on the left, or a part of the 'Great Society' during the 1960 s, took the threat of a right-wing cultural insurgency seriously in the 1960s (pp. 81-82). Their opponents were hardly so sanguine. As Lisa McGirr explains, this right-wing counter-hegemonic offensive began in California in the early-1960s. These activists were profoundly alienated from the 'big society' being built around them. Their goal was to level it, creating an alternative version of post-war America in its place: a new utopia "revolving back ... to the foundations of society" before the "internal communist conspiracy" that forged the welfare state came into being (McGirr, 2001, p. 4, 75).

For the new right - as for the 1960s radical democrats - schools were an essential part of their political project. They perceived their children as being subjected to 'liberal' indoctrination in public schools - represented by "displays of the United 
Nations in school hallways," "sex knowledge inventory tests," and "progressive education," writ large. As one aggrieved parent put it: "Our child in kindergarten was taught evolution. Her religion was ridiculed and her confidence in her parents was shaken" (McGirr, 2001, p. 75). The solution for the new right was to remove their children from those schools, while setting up an alternative educational apparatus, consisting of "little platoons of society" - beachheads in the greater war against postwar liberal society (Rodgers, 2011, pp. 214-219).

These platoons would be realized through school vouchers: tax-supported grants that parents could 'spend' by placing their children into any number of privately run schools. Catholics approved of this "relief from the double burden of public school taxes and parochial school fees," while white segregationists were enthusiastic about escaping the consequences of the 1954 Brown v. Board of Education Supreme Court decision (Rodgers, 2011, pp. 214-215).

In the 1970s and 1980s, vouchers were taken up by others with academic cache, including the high-profile economist and public intellectual, Milton Freidman. Here, we see an important shift: a change of emphasis from religion and race to a neo-liberal conception of free markets as an educational (and by extension, social) panacea (Ravitch, 2011, p. 4). A major breakthrough was achieved between 1988 and 1990 with the publication of John Chubb and Terry Moe's Politics, Markets and America's Schools. In this work, the authors "merged the radical school critique of the 1960s with the market fundamentalism of the 1980s," arguing that what made private schools succeed was freedom from bureaucracy and educational experts of all kinds (Rodgers, 2011, p. 216). What should take their place? The "natural dynamics of competition and choice," from which would flow "accountability, responsiveness, effectiveness, teacher teamwork, and bottom-up control” (quoted in Rodgers, 2011, p. 216).

Mainstream Republicans like Chester Finn quickly saw the potential of 'school choice' as a means of advancing a broadly neo-liberal agenda. At this same moment, high-level Democrats including Albert Shanker, President of the Teachers' Federation of America, was also arguing for 'choice' as a means of realizing a new iteration of progressive education. As Shanker argued, educators should be given "charters" - or grants - to start up alternative schools. These 'charter schools' would employ new pedagogies "for five or ten years, as long as parents and teachers continued to support the experiment." (Kahlenberg, 2007, p. 311). Though Shanker recoiled from the plan when he realized that charters would inevitably draw "for-profit corporations" and "anti-union advocates" into education, the damage was already done (p. 313).

Neo-liberal charter advocates did extremely effective organic intellectual work. They opened 'lighthouse' charter schools to demonstrate their ideas, lobbied governments for ever more political and financial support, and most importantly, turned themselves into expert voices on education for the mainstream media - always sure to steer the conversation back to the virtues of charter schooling, and the vices of the public system. Soon enough, the neo-liberal educational panacea was in vogue, attracting the support of billionaire philanthropists like Bill and Melinda Gates and Mark Zuckerberg, as well as those, such as Rupert Murdoch, who were simply 
looking for new markets to exploit.

By the 2000s, the process was complete. What began as a small, counter-hegemonic project in California now reached to the highest levels of government in the US and UK. The administrations of Barack Obama and David Cameron both created coercive mechanisms for replacing public schools with charters and 'academies' (as they are known in the UK), tying the public system's very existence to high performance on standardized tests - the sort of tests that charter schools, relatively free from curricular oversight, can specialize in. It is a systemic shift, designed to allow charters to triumph.

By this time the charter school model had solidified. These schools would be small and utilitarian in nature, geared toward preparing children and young people for the demands of the contemporary job market, as directly as possible. They would employ more discipline than public schools would allow, to do so. The liberal arts, which were traditionally used to cultivate "intellectual creativity, autonomy ... critical thinking ... the comprehension and tolerance of diverse ideas and experiences [and] informed participation in community life" were sidelined, and rendered 'nonessential' in this new pedagogical model (Axelrod, 2002, pp. 34-35; Ravitch, 2014).

With American Democrats and the British Coalition (Tory/Liberal-Democrat) government fully on board, one would expect the left to wage war against this novel form of neo-liberal coercion. Yet, it has been largely silent, for after the 1960s, many educational radicals abandoned public education as a radical democratic cause, to make a new home for themselves in university-affiliated Faculties of Education. From there, they launched caustic attacks on public schooling, while failing to perceive and thus to fight - the new right's much more damaging assault on public education.

\section{The Marxist structural critique}

As Echols (2002) points out, at the beginning of the 1960s, even the most radical new leftists subscribed to a "humanist" liberalism that could be separated from its "corporate" counterpart (pp. 79-80). By the end of the decade however, this distinction had dissolved. The growth of US corporate capitalism, the assassination of Civil Rights and Black Power leaders, and the war-machine in Vietnam all overshadowed radical democratic advances, including "youth, health, antipoverty, urban, and conservation programs" (Bookchin, 1999, p. 72). What replaced those advances was a new pessimism regarding the state's role in post-war life. In this new, more jaded stance, "'the system' [became] the target” (Elbaum, 2006, p. 15). In education, too, confidence crumbled. After the massive build-up of the educational apparatus in the 1960s, seemingly minimal educational and social returns by the end of the decade soured the pedagogical utopianism of early-to-mid 1960s. By the end of the decade an aura of "scorn, disappointment, and despair" surrounded public education (Bookchin, 1999, p. 15, 239).

In short order, a new structure of feeling - or, a new, mobile alignment between concrete historical circumstances and people's conceptions of those circumstances emerged among educational radicals: a dystopian frame of mind in which the oppressive 'structures' of schooling and the profoundly unjust society they produced and 
reproduced came to the fore (Williams, 1997, pp. 128-129). What was jettisoned was any talk of the individual and their liberation through education, now considered a relic of the discredited 1960s.

We can see this structure of feeling manifested in the most influential thinkers on education and society beginning in the 1970s, and carrying on into 1980s, 1990s, and even into the present. French philosopher Louis Althusser has proved extremely influential in this respect. He initially won fame through a book of essays entitled For Marx (1965), in which he argued that the "humanist" Marx championed by the likes of György Lukács and Sartre was a chimera, a mere phase through which Marx passed before arriving at maturity with Capital, which treated capitalist society 'scientifically' - that is, as a complex series of overlapping ('overdetermined') social structures (Althusser, 2005, pp. 229).

More important still was a 1969 essay entitled "Ideology and Ideological State Apparatus (Notes Towards an Investigation).” Here, Althusser turned to the question of how stratified societies reproduced themselves. They did so in two ways: on one side, through a "repressive state apparatus (the military, the police, the courts, and so on), and an "ideological" state apparatus (family, schools, media, religious institutions) on the other. For Althusser, the second was far more important - this was where modern power lay. As he argued, public schooling saw students snatched from their families, and kept for hours, days, and years in a controlled environment in which the explicit content of capitalist societies (embodied in civics, for instance) as well as more subtle forms of social control, like being punctual, holding one's pen correctly, and taking instruction without complaint - were absorbed by the afflicted students (Althusser, 2001, p. 105). Althusser's concerns - anti-humanism, the unconscious nature of ideology, and the body as the locus of social stratification - have reverberated powerfully in educational studies, not least through the influence of his student, Michel Foucault.

The work of Pierre Bourdieu furthered this rejection of the radical humanism and democracy of the 1960s. His book with Jean-Claude Passeron, Reproduction in Education, Society, and Culture (1977), treats education as a sophisticated form of symbolic violence in which class-structures are reproduced through "the imposition and inculcation of a cultural arbitrary by an arbitrary mode of imposition and inculcation" - that is, through public schooling. In 1984's Distinction, he furthered his critique, developing the concept of "cultural capital" as a means of understanding the reproduction of unequal societies. For Bourdieu, there is a clear correlation between monetary wealth (or capital, proper) and symbolic or cultural capital (a familiarity with 'classic' books, skill in argument, and correct physical bearing in the classroom). For Bourdieu, those with sufficient cultural capital enter the educational process with an inbuilt advantage that leads to school success, and later wider prosperity in business or government. Further, that success will seem 'natural,' thus obscuring its profoundly cultural origins. Those with cultural capital will then pass it to their own children. In this way, class structures are reproduced, time and again, despite widely proclaimed liberal promises of meritocracy through education (Bourdieu, 1984; Bourdieu \& Passeron, 2001). 
Bourdieu's colleague and friend, the British sociologist Basil Bernstein, took this critique into the realm of linguistics - and thus even further into abstract structuralism. Bernstein asserted that the very matrices of language were the key site of class reproduction. Working-class kids were born into a "restricted" language environment that limited their understanding, imagination, and logical facilities, and thus their educational and social prospects in post-war society. On the contrary, children born into wealthy families inherited "elaborated speech codes," which gave them an infinitely useful tool for ascertaining their circumstances, reimagining them, and thus transforming them - the kind of cultural mastery perfectly suited to capitalist society. Just like the pupils in Bourdieu's work, they would pass on this cultural privilege to their children (Bernstein, 1977, p. 477).

The American scholars Samuel Bowles and Herbert Gintis' Schooling in Capitalist America: Educational Reform and the Contradictions of Economic Life (1976) was a landmark in 1970s North American educational criticism. These scholars explicitly targeted the radical democratic vision of the educational state, built up over the course of the 1960s. As they argued, it was based upon a "hardy optimism that social programs can be used to alleviate social distress and restore a modicum of social harmony" (Bowles \& Gintis, 1976, p. 5). In reality, for Bowles and Gintis, this educational state served a dual purpose, neither of them socially just: it deflected attention away from the unequal and alienating economic structures underpinning schooling, and it solidified those structures by creating compliant and carefully-sorted future-workers through school discipline, IQ tests, guidance counselling, and 'progressive' initiatives such as special education (p. 11). For Bowles and Gintis, no piecemeal alteration would halt this advance. Only wholesale rejection of capitalism would change the educational edifice.

With British cultural studies - particularly at the University of Birmingham in the 1970 s - this structural critique became more subtle and elaborate. Paul Willis' classic study Learning to Labour: How Working Class Kids Get Working Class Jobs (1977) is both an ethnographic account of working-class schoolchildren in 1970s Britain, and a theoretical account of class reproduction through education. Willis' innovation was to suggest that the process of reproduction was complex, subjective, and contradictory. That is, there was no one-to-one correspondence between social structure and class relations. Instead, there was a "certain creativity" in the transference of one to the other that allowed those structures to be modified as they were reproduced in the pupil's subjective experience (Willis, 1977, p. 121). This opened up the possibility of resistance. Despite this possibility, Willis argued that this creative reproduction was often too weak and unfocused to make a genuine difference in the lives of workingclass students. More ominously, any minor rebellion they might throw at the system would only translate into a "subjective affirmation" of it, and their place within it (p. 121).

Critical pedagogy, embodied here in the work of Henry Giroux, marks an important break in this pattern. In a 1983 essay, "Theories of Reproduction and Resistance in the New Sociology of Education," Giroux took Bowles, Gintis, and Willis to task for relying too heavily on what he dubbed the "Economic-Reproductive Model" of 
schooling. This theoretical structure reduced schooling to a mere legitimation of "dominance and subordinance in the economic sphere" (Giroux, 2006, p. 8). Giroux argued that this approach was crucial, yet limited. Instead, he argued that scholars should take this structural critique and dialectically intertwine it with Willis' notion of resistance. For Giroux, resistance was a break from structure, not a capitulation to it. What could and should result from student rebellion against the school was a new, critical relation to education, and the social structures underpinning it. That is, a new state of "intentionality" and "consciousness," which could be pushed towards an interrogation of hegemonic "common sense" by the student (p. 36).

Critical pedagogy indeed breaks with structural critique, but does not go far enough; it remains at a level of sociological, positivist abstraction, rather than taking the flesh-and-blood young people at the centre of the educational process as the sine qua non of a liberatory conception of schooling - the sort that would have been commonplace in the long-1960s. Now we will turn to two thinkers that can help us to find our way back to public education as a radical democratic project: the Canadian philosopher C. B. Macpherson, and the Italian theorist and activist, Antonio Gramsci. In "possessive individualism," Macpherson gives us a crucial tool for understanding the nature of neo-liberal education reform, while Gramsci points us toward the radical potential of liberal education, the beating heart of the public school.

\section{C. B. Macpherson, liberalism, and possessive individualism}

The Canadian philosopher C. B. Macpherson was a political thinker of world-renown in the 1960s and 1970s, though he fell out of favour after that point. Something of a Macpherson revival seems to be underway, as some leftists seek to reconcile themselves to liberalism, and as some liberals seek to go beyond the limits of liberal thought, to incorporate the structural critique of capitalism into their own political projects. His critiques of "possessive individualism" are immensely useful for exploring the past and present of the new right and educational neo-liberalism.

Macpherson (1911-1987) was trained at the University of Toronto and the London School of Economics. By the 1950s, he became one of the world's most renowned interpreters of the liberal tradition. The Political Theory of Possessive Individualism: From Hobbes to Locke (1962) established his world reputation and made "possessive individualism” a household phrase (at least for a time and in particular places).

Macpherson was plainspoken about his underlying project. He sought to help liberals understand and respond to the modern age, and enlisted Marxist thought to this end. When asked about the elements of the liberal tradition he considered valuable and sought to preserve, he mentioned John Stuart Mill's "view of human nature as developmental, amounting to the full and free enjoyment and development of human capacities, everyone's capacities," and at a less abstract "operative" level, particular civil and political freedoms: "freedom of speech, association, publication, etc.; freedom from arbitrary arrest and imprisonment; freedom to exert political pressures whether by vote or in other ways" - in general, liberal civil and political liberties (Cunningham, 1994, p. 16-17). 
For Macpherson, the essence of human nature resided in exerting and developing capacities. Any political theory worthy of respect - that is, capable of being relevant for moral and political life - must tie the state "back to supposed essential human purposes and capacities, to a supposed essential nature of man" (cited in Lindsay, 1996, p. 13). In a well-governed political and social order, the properties of the free self-developing individual - including "the capacity for rational understanding, for moral judgment and action, for aesthetic creating or contemplation for the emotional activities of friendship and love, and sometimes, for religious experience" - would be subject only to the limitation that they do not deny or impede the exercise of such properties by other individuals. Labour - the capacity to do, exert, create - is thus essential to humanity, and "socially destructive capacities" are, implicitly, nonbuman (Lindsay, 1996, p. 28; Macpherson, 1977, p. 4).

Further, human capacities, "to be fully human, must be under one's own conscious control rather than at the dictate of another," and all must enjoy "equal right ... to develop their capacities to the fullest" (Macpherson, 1977, p. 56-57). We can see clear links between this form of leftist/liberalism - or, rather, liberal/leftism - and classic expressions of progressive education, as found in the work of John Dewey, for instance. As Dewey wrote in Democracy and Education (1916), education, at its root, makes this self-development possible. It represents "a positive force or ability - the power to grow" (Dewey, 2008, p. 47).

This human nature - inclined toward growth and development, best realized among equal individuals - was thwarted by the development of capitalism, which wrenched those individuals away from their nature, towards what Macpherson called "possessive individualism" - a narrowing of human nature and its possibilities under capitalism. He provided a useful distillation in Democratic Theory:

(1) Man, the individual, is seen as absolute natural proprietor of his own capacities, owing nothing to society for them. Man's essence is freedom to use his capacities in search of satisfactions. This freedom is limited properly only by some principle of utility or utilitarian natural law which forbids harming others. Freedom therefore is restricted to, and comes to be identified with, domination over things, not domination over men. The clearest form of domination over things is the relation of ownership or possession. Freedom is therefore possession. Everyone is free, for everyone possesses at least his own capacities.

(2) Society is seen, not (as it had been) as a system of relations of domination and subordination between men and classes held together by reciprocal rights and duties, but as a lot of free equal individuals related to each other through their possessions, that is, related as owners of their own capacities and of what they have produced and accumulated by the use of their capacities. The relation of exchange (the market relation) is seen as the fundamental relation of society.

Finally (3) political society is seen as a rational device for the protection of property, including capacities; even life and liberty are considered as possessions, 
rather than as social rights with correlative duties. (Macpherson, 1977, p. 199)

Neo-liberal education is based upon such a possessive individualist reduction of human nature. Instead of fostering creative, democratic, independent learners, neoliberal schooling seeks to reduce the process of education to a relationship of mere utilitarian exchange. The resources of Macpherson's developmental-democratic liberalism can once again be marshalled against possessive individualist schooling, not least through liberal arts education - a form of pedagogy that takes on new political significance in a cultural environment in which market-driven, utilitarian schooling has become hegemonic. Gramsci, a Marxist thinker, points us in this direction.

\section{The Gramscian challenge to educational orthodoxy}

Like Macpherson, Gramsci sought to challenge reductive liberalisms that stunted human possibilities. To this end, he contrasted liberalismo (the philosophy of freedom) - and liberismo (a liberalism overdetermined by capitalist values). Gramsci saw liberismo as a clear challenge to freedom - and, one might say today, to human survival. Importantly, for Gramsci, schools and tertiary educational institutions were crucial locations of wider cultural/political struggles; more specifically, all education was political and all political activity was educational.

For Gramsci, liberalismo was fundamentally pedagogical. Human freedom was tied to emancipatory knowledge-production and dissemination, based upon freedom of research and inquiry, and disciplined exploration and self-discovery through the liberal arts. He saw education as a voyage of "self-knowledge, self-mastery and thus liberation" through the acquisition of the skills of logical and empirical analysis, combined with a sensitivity to the arts and culture in a broader sense (Gramsci, 1971, p. 350).

His concern for the emancipatory potential of the liberal arts makes Gramsci unusual among the Marxists of his time. For him, it was a sign of weakness on the part of radicals to discount the cultural work of those who had preceded them. As he wrote: "A generation that devalues the previous generation and is incapable of recognizing its great achievements and its essential significance is bound to be mean and lacking in self-confidence, even if it displays gladiatorial postures and a craving for greatness" (Gramsci, 2007, p. 164). Gramsci perceived the new order for which he fought so strenuously to be one that widened the scope of liberal culture, making it available to all, and not just "restricted sections of the population" (p. 164). Herein lies the resonance of Gramsci for our discussion of possessive individualism in education, and how it might be overcome: he sought not the destruction of liberalism nor the smashing of its cultural legacy, but its dialectical sublation in a new political and philosophical world in which its promise was finally realized.

For Gramsci, an education in the broad sense - one that extended far beyond strictly "scholastic" relationships - entailed a new generation encountering the experiences of the old, absorbing "its experiences and its historically necessary values," while developing a personality of its own which is historically and culturally superior (Gramsci, 2007, p. 350). Genuine revolutionaries were not those who simply wanted 
to destroy bourgeois civilization. Rather, they were those who understood and realistically evaluated the "whole of past thought" (p. 344). This meant liberation from the blinders of "ideological fanaticism" and "taking up a point of view that is 'critical,' which for the purpose of scientific research is the only fertile one" (p. 51). In short, Gramsci urged his fellow (what we would now call) activists to reclaim the liberal arts (and the radical democratic mindset it fosters) for revolutionary ends.

Gramsci's ideal radical democratic educational program would be comprised of a "common basic education, imparting a general, humanistic, formative culture" after which (and only after which) students would enter a utilitarian phase of education. (p. 27). For Gramsci, this initial pedagogical immersion in art, culture, history, and philosophy was essential for creating a fully-rounded, critical citizenry, capable of creating, expanding, and defending radical democratic values. As he put it, through this process, all children and young people would become "capable of thinking studying and ruling - or controlling those who rule” (Gramsci, 1971, p. 259).

This end was a profoundly democratic one: to awaken in students a common attachment to the shared adventure of humankind as it pushed back the frontiers of knowledge and an ever-growing capacity to engage critically and intelligently with the world, not to sacrifice certain children to utilitarian ends, nor "impose" upon them systems of thought unrelated to their lives. (p. 164) Gramsci shows us how liberal education in the public school can be a radical, democratic force - and thus a source of counter-hegemonic revolution against neo-liberal schooling and society.

\section{Signs of hope}

Finally, we will examine two thinker/writer/teachers, and two large-scale events that show us that radical democracy in education has indeed survived, and could perhaps be on the march in our own time. These thinkers and activists understand that neo-liberal education shifts the developmental democratic nature of children and young people from liberalismo to liberismo (or possessive individualism), and that liberal education proper can be used to restore and preserve what has been lost under the hegemony of the new right. In this, they offer hope in the face of a grim, contemporary reality.

The American philosopher Maxine Greene (1917-2014) long held fast to the radical democratic position while it was absolutely unfashionable to do so. Now, as criticism of neo-liberal education gathers steam, her work reads as prophetic. It is at once a powerful critique of education as possessive individualism, and an exploration of liberal education as a means of enhancing individuality and utopian democracy. In her classic essay, "Wide-Awakeness and the Moral Life" (1978), Greene argues that possessive individualist social forces are deeply damaging to the aims and objectives of education. The schools of the late-1970s were rife with vested interests, according to Greene (1978) - from a "proliferation of bureaucracies" to a plethora of corporate structures," experienced in the classroom as an unending series of alienating "schedules, curricula, and testing programs" (pp. 43-44). These factors stood directly against the genuine goals of education - the promotion of individual agency, moral intelligence, and a sense of social justice in children and young people allowing them 
to develop the "capacities" they have, while steering them toward a critical sense of the "the consequences of [their] acts." This is what Greene calls 'wide-awakeness' individual and social growth through the (liberal) content and processes of education (p. 47).

In a now-classic lecture series delivered at Teachers College in 1988, collected as The Dialectic of Freedom, Greene addressed what we now call neo-liberalism directly. As an existentialist, she was alarmed by the reduction of educational freedom to mere 'school choice' (Greene, 1988, p. 18). This was not freedom or choice in any meaningful sense for Greene; rather, it was a market-driven utilitarianism which expunged all utopian possibility from education, as the "dominant watchwords" in pedagogical discourse became "effectiveness," "proficiency," "efficiency," "and an ill-defined, one-dimensional "excellence" (p. 12). This turned the school into a mere processingunit, churning out "human resources" for an "increasingly systematized world" (p. 12). This vision of education contributed to a dangerous and deadening hegemony, training children and young people to accommodate themselves to "existing social and economic structures, to what is given, to what is inescapably there" (p. 12). This ran directly counter to the utopian role that liberal education played for Greene. She saw immersion in the liberal arts as a radically humanizing force, in which critical engagement with cultural tradition became the basis for "self-dependence," "selfdetermination," and "connectedness or being together in a community" (p. 1).

bell hooks - literary theorist, cultural critic, feminist thinker, memoirist, and children's book author - is, like Althusser, Bourdieu, Bowles and Gintis, and Willis, deeply attuned to the overdetermining factors of class, race, and gender in education. And yet, she is just as concerned with individual "intellectual and spiritual growth," through schooling and higher education (hooks, 1994, p. 13). Thus, her concerns remain closer to the radical democratic utopians of 1960s than the leftist structural critics who came afterward. She categorically rejects the possessive individualism of the neo-liberals as well.

In her Teaching to Transgress: Education as the Practice of Freedom (1994), hooks asserts that her radical democratic concerns derive from her immersion in feminism, where serious attention was paid to a pedagogy of 'consciousness-raising,' in which the personal experiences of students were articulated with larger structural factors. This dialectic then gave rise to a third position: "education as the practice of freedom" (hooks, 1994 , p. 13). This approach to teaching and learning was reinforced by hooks' contact with the Brazilian educator Paulo Freire and the Vietnamese Buddhist monk, Thich Nhat Hanh. From Freire, she learned that a possessive individualist approach to education - in which knowledge was considered mere information to be 'banked' by the student for later, utilitarian use - should be rejected in favour of "conscientization," or shared "critical awareness and engagement" between teacher, student, and the educational tradition (p. 14). From Hanh, she learned that education should emphasize "wholeness" - an education of mind, body, and spirit (pp. 14-15).

In an essay entitled "Confronting Class in the Classroom," hooks argues for the importance of experience in education - an idea that harkens back to Dewey, and echoes Greene. Experience begins with the structural, but this is structure as lived 
by individuals. These structures are reproduced through education because they are "passed over in silence in the classroom," rather than being critically examined by students and teachers (hooks, 1994, p. 177). Those most affected by class constraints are the most victimized by this silence, for they censor themselves out of fear of betraying "anger," or "emotional outbursts" - qualities that mark them as outsiders. These barriers undermine "the democratic exchange of ideas," while reproducing deep inequalities through education (p. 178). Confronting these experiences in the safe space of a radical democratic classroom - where students learn to see these structures as cultural and thus not determinative - is the first step towards creating a liberatory critical consciousness, which would ultimately lead to conscientization on a social scale (p. 189).

This strain of radical democracy also animates contemporary large-scale projects and practical interventions. One of the most important is found in contemporary Chicago. Since the turn of this century, Chicago has been the world's storm centre for neo-liberal education reform. Not coincidentally, it is also the location of the most focused and powerful movement against it, through the newly politicized Chicago Teachers' Union. In 2004, Mayor Richard M. Daley and the new CEO of the Chicago Public Schools (later to become Barack Obama's Secretary of Education) Arne Duncan implemented a plan they dubbed "Renaissance 2010." This 'rebirth' of the city would occur through education reform, more specifically through the imposition of charter schools upon Chicago communities. This policy saw all Chicago public schools deemed 'low performing' (that is, failing to deliver high standardized test scores), shuttered, and "turned around" - or replaced by privately underwritten and controlled charters (Uetricht, 2014).

In response, many parents began agitating against Renaissance 2010. The Chicago Teachers Union was initially slow to join them. This did not stop a rump of the CTU rank-and-file from taking action, however. These teachers aligned themselves with parents against the city, and the union leadership alike. This grassroots response to neo-liberal schooling took definitive shape as the Caucus of Rank-and-File Educators, or CORE. These leftist organic intellectuals took it upon themselves to master their new terrain, immersing themselves in the fine-print of the education laws erected by Daley and Duncan, and in critical literature on education and society - most notably Naomi Klein's The Shock Doctrine (which argued that the new right used economic and social 'shocks' - 9/11 and Hurricane Katrina, for instance - to further neo-liberal social reforms). They also vigorously defended the liberal arts against neo-liberal attacks, stressing their importance for the full development of children and young people. CORE soon attained leadership of the CTU, and declared that the organization would oppose all education reform projects in America that put profits before individual growth and social justice. The Union then staged a remarkable 2012 protest which saw 30,000 supporters close down the city-centre in protest against what was now referred to as 'educational deform' by CORE. The experience of being a part of CORE proved deeply educational for those involved. As one teacher put it: "After being degraded by the corporate media, the mayor and his henchmen ... taking a stand for ourselves, our children and our community restored 
us to the level of human beings" (Marchetti, 2014; Uetricht, 2014).

Our final example is one that represents a national alternative to neo-liberal education: that of post-war Finland. Like most countries after 1945, Finland took a long, hard look at its school system, and found it wanting. During that period, the country was governed by a coalition of social democrats, communists, centrists, and conservatives (Sahlberg, 2011, p. 16). They agreed on little, but they did agree that any national education system worth its salt had to be a comprehensive (academic and vocational) one. A number of educational commissions and reports followed, and by the later-1960s, a new system took shape: one in which compulsory education was definitively extended, private schools were discouraged, and a general "progressive, future-oriented" educational direction was established, in which both individual growth and social justice were emphasized (p. 20). Crucially, the liberal arts were foregrounded, just as other Western countries began to lose faith in their democratic potential.

By 1970, these changes were enshrined in a national curriculum. It echoed the radical democratic coalition that formed in the Anglo-American world in the 1960s, but the Finnish system moved from strength to strength, as its Anglo-American counterparts were slowly desiccated. This system is now hegemonic in Finland, encouraging the best and brightest to become teachers - which is among the most esteemed professions in the country.

It is the Finnish school system's legal responsibility to educate each child equally (Sahlberg, 2011, p. 21). All children and young people must proceed through the same nine years of schooling, although the "content, organization, and pace" of their individual progression is as flexible as possible, so that all Finns can receive the same 'head start,' regardless of socio-economic background (p. 21). Special education is commonplace, rather than a deviation from the mainstream, public system. Guidance counselling is also a major part of the public system, ensuring that few

grades are repeated, and premature school-leaving is minimized (p. 23). Finally, all teachers are highly educated, in both liberal subject matter and pedagogy, and are all expected to work with extremely diverse groups of students.

Crucially, these measures are seen as extensions of Finland as a social democracy. This is expressed through the philosophy of peruskoulu, in which all teachers and students learn "through human diversity," within schools conceived as "small-scale democracies, just as John Dewey had insisted" (p. 21). Diane Ravitch is one of the many scholars that have pointed toward Finland as an example of a society that has rejected possessive individualism in education, while proving that radical democratic schools can beat the neo-progressives at their own game - Finland has, in recent years, come to be seen as an 'education superpower,' consistently placing near the top of international education rankings beginning in the early 2000s. (Ravitch, 2010).

\section{Conclusion}

One of the most powerful weapons in the neo-liberal arsenal is the assertion that - in the words of Margaret Thatcher - "there is no alternative." That is, for neo-liberals, we are to consider ourselves hostage to social forces beyond our control, rather than 
seeing our contemporary condition as the result of "history and politics" (McKay, 2005, pp. 8-9). In this reconnaissance, we have attempted to show that neo-liberal education reform was and is anything but natural. The ideas behind it were not the 'best,' or the most 'progressive' on offer. They did not rise to the top on their own accord. Rather, they were fought for by flesh-and-blood activists, determined to wage pedagogical war to make them seem natural, and not the products of cultural struggle. We believe that there is much to be learned from the new right about how to create, defend, and make commonsensical a conception of education that is individually liberatory and socially just - seen by all as the natural right of all. Margaret Thatcher was a master of such politics and the attendant construction of political realities. But this does not mean that she was correct. Far from it. There are always alternatives, provided that the collective will exists to create them, see them realized, and hold the ground when reaction comes, as it must.

\section{Notes}

1. For an important analysis focused on Canadian historiography that compliments the argument offered here, see Bruno-Jofré, R. (2014). History of education in Canada: Historiographic "turns" and widening horizons. Paedagogica Historica: International Journal of the History of Education, 50(6), 774-785.

2. See also Fourastié, J. (1979). Les Trente glorieuses ou la Révolution invisible de 1946 à 1975. Paris, France: Fayard.

3. See also Hartman, A. (2008). Education and the Cold War: The battle for the American school. New York, NY: Palgrave Macmillan.

\section{References}

Althusser, L. (2001). Lenin and philosophy and other essays. (B. Brewster, Trans.). New York, NY: Monthly Review Press.

Althusser, L. (2005). For Marx. (B. Brewster, Trans.). London, England, and New York, NY: Verso.

Axelrod, P. (2002). Values in conflict: The university, the marketplace, and the trials of liberal education. Montreal, QC, and Kingston, ON: McGill-Queen's University Press.

Bernstein, B. (1977). Social class, language and socialization. In J. Karabel \& A. H. Halsey (Eds.), Power and ideology in education (pp. 473-486). New York, NY: Oxford University Press.

Bookchin, M. (1999). Anarchism, Marxism and the future of the left: Interviews and essays 19931998. Edinburgh, Scotland, and San Francisco, CA: AK Press.

Bourdieu, P. (1984). Distinction: A social critique of the judgement of taste. (R. Nice, Trans.). Cambridge, MA: Harvard University Press. 
Bourdieu, P., \& Passeron, J.-C. (2001). Reproduction in education, society, and culture. (R. Nice, Trans.). London, England, Thousand Oaks, CA, and New Delhi, India: Sage.

Bowles, S., \& Gintis, H. (1976). Schooling in capitalist America: Educational reform and the contradictions of economic life. New York, NY: Basic Books.

Clune, M. W. (2013, February 26). When was neo-liberalism? The Los Angeles Review of Books. https://lareviewofbooks.org/review/what-was-neoliberalism

Cunningham, F. (1994). The real world of democracy revisited. Atlantic Highlands, NJ: Humanities Press.

Dewey, J. (2008). The middle works of John Dewey, Vol. 9, 1899-1924: Democracy and education, 1916. J. A. Boydston (Ed.). Carbondale, IL: Southern Illinois University Press.

Echols, A. (2002). Shaky ground: The sixties and its aftershocks. New York and Chichester, NY: Columbia University Press.

Elbaum, M. (2006). Revolution in the air: Sixties radicals turn to Lenin, Mao and Che. London, England, and New York, NY: Verso.

Entwistle, H. (1978). Antonio Gramsci and the school as hegemonic. Educational Theory, I, 23-33. http://dx.doi.org/10.1111/j.1741-5446.1978.tb00790.x

Giroux, H. A. (2006). Theories of reproduction and resistance in the new sociology of education. In C. G. Robbins (Ed.), The Giroux reader (pp. 3-46). Boulder, CO: Paradigm.

Gramsci, A. (1971). Selections from the prison notebooks of Antonio Gramsci. New York, NY: International Publishers.

Gramsci, A. (2007). Prison notebooks, Vol. 3. J. Buttigieg (Ed. and Trans.). New York, NY: Columbia University Press.

Greene, M. (1978). Landscapes of learning. New York, NY, and London, England: Teachers College Press.

Greene, M. (1988). The dialectic of freedom. New York, NY, and London, England: Teachers College Press.

Hobsbawm, E. (2004). The age of extremes: The short twentieth century, 1914-1991. London, England: Abacus.

hooks, b. (1994). Teaching to transgress: Education as the practice of freedom. New York, NY, and London, England: Routledge.

Kahlenberg, R. D. (2007). Tough liberal: Albert Shanker and the battles over schools, unions, race, and democracy. New York, NY: Columbia University Press.

Kliebard, H. (2004). The struggle for the American curriculum, 1893-1958. New York, NY: Routledge.

Lindsay, P. (1996). Creative individualism: The democratic vision of C. B. Macpherson. Albany, NY: State University of New York Press.

Lowe, R. (2007). The death of progressive education: How teachers lost control of the classroom. London, England, and New York, NY: Routledge.

Macpherson, C. B. (1977). Democratic theory: Essays in retrieval. Oxford, England: Clarendon Press.

Marchetti, M. (2014, May 7). The striking lessons we learned. Socialist Worker. http://socialistworker.org/2014/05/07/the-striking-lessons-we-learned

McGirr, L. (2001). Suburban warriors: The origins of the new American right. Princeton, NJ: Princeton University Press. 
McKay, I. (2005). Rebels, reds, radicals: Rethinking Canada's left history. Toronto, ON: Between the Lines.

McKay, I. (2008). Reasoning otherwise: Leftists and the people's enligbtenment in Canada, 1890-1920. Toronto, ON: Between the Lines.

Miller, J. (1987). Democracy is in the streets: From Port Huron to the siege of Chicago. New York, NY: Simon \& Schuster.

Mills, C. W. (1967). Power, politics \& people: The collected essays of C. Wright Mills. I. L. Horowitz (Ed.). London and Oxford, England, and New York, NY: Oxford University Press.

O'Hara, G. (2007). From dreams to disillusionment: Economic planning in 1960s Britain. Basingstoke, England, and New York, NY: Palgrave Macmillan.

Peers, A. E. (1943). Red brick university. London, England: Faber \& Faber.

Ravitch, D. (1983). The troubled crusade: American education, 1945-1980. New York, NY: Basic Books.

Ravitch, D. (2010, November 11). The myth of charter schools. The New York Review of Books. http:/www.nybooks.com/articles/archives/2010/nov/11/myth-charter-schools/

Ravitch, D. (2011). The death and life of the great American school system: How testing and choice are undermining education. New York, NY: Basic Books.

Ravitch, D. (2014, March 27). New York schools: The roar of the charters. NYR Blog. http:// www.nybooks.com/blogs/nyrblog/2014/mar/27/new-york-charters-against-deblasio/

Rodgers, D. T. (2011). Age of fracture. Cambridge, MA, and London, England: Harvard University Press.

Sahlberg, P. (2011). Finnish lessons: What can the world learn from educational change in Finland? New York, NY, and London, England: Teachers College Press.

Uetricht, M. (2014, March 6). Uncommon CORE. Jacobin. https://www.jacobinmag. com/2014/03/uncommon-core-chicago-teachers-union/

Williams, R. (1977). Marxism and literature. Oxford, England: Oxford University Press.

Willis, P. (1977). Learning to labour: How working class kids get working class jobs. Farnborough, England: Saxon House.

Wilson, J. D. (1977). From the swinging sixties to the sobering seventies. In J. D. Wilson \& H. A. Stephenson (Eds.), Precepts, policy and process: Perspectives on contemporary Canadian education. London, ON: Alexander, Blake Associates. 
